\section{'NuMex Snowball' Onion}

\author{
Christopher S. Cramer ${ }^{1}$ and Joe N. Corgan ${ }^{2}$ \\ Department of Agronomy and Horticulture, Box 30003, MSC 3Q, New Mexico \\ State University, Las Cruces, NM 88003-0003
}

Additional index words. Allium cepa, vegetable breeding, Phoma terrestris

The New Mexico State Univ. Agricultural Experiment Station announces the release of 'NuMex Snowball' onion (Allium cepa L.). 'NuMex Snowball is a late-maturing, pinkroot-resistant, round, hard, intermediate-day, white-colored onion cultivar for spring seeding in southern New Mexico and similar environments, maturing in late July when springseeded in Las Cruces, N.M.

\section{Origin}

'NuMex Snowball' was selected from a population formed by intercrossing 'Ringmaster', a white selection from 'Texas Early Grano 502 PRR', 'Temprana', 'Snow White', and a pink-root-resistant selection from 'New Mexico White Grano' in 1980. 'Ringmaster' is a long-day, 'White Sweet Spanish'-type onion that matures late when spring-planted in southern New Mexico. It produces high yields of large globe bulbs and is moderately resistant to pink root. 'Texas Grano 502 PRR' is a pink- root-resistant selection from 'Texas Grano 502' (Corgan, 1984). 'Texas Grano 502 ' was selected from 'New Mexico Early Grano' that originated from lines introduced from Spain labeled as 'Valencia Grano' (Corgan, 1984; Garcia and Fite, 1931). 'Texas Early Grano 502 PRR' is a short-day, yellow onion that matures early when fall-planted in southern New Mexico; however, sometimes white onions have appeared in this line. 'Texas Early Grano 502 PRR' is top-shaped and produces large bulbs that are low in pungency and soluble solids, have soft flesh and few dry scales, and store for short periods of time (Hawthorn, 1944). 'Temprana' is a selection out of 'New Mexico White Grano', and was released by the New Mexico Agricultural Experiment Station in 1979 (Enzie and Corgan, 1979). 'New Mexico White Grano' was originally selected out of 'New Mexico Early Grano' in 1930 by the New Mexico Agricultural Experiment Station. 'New Mexico White Grano' produces high yields of large top-shaped white bulbs, is moderately pink root resistant, and is susceptible to bolting. 'Temprana' is a shortday, white onion that matures early when fallplanted in southern New Mexico (Enzie and Corgan, 1979). It is top-shaped and produces large bulbs with characteristics similar to

Received for publication 13 Nov. 2000. Accepted for publication 5 May 2001. This research was funded by the NMSU Agricultural Experiment Station and the New Mexico Dry Onion Commission. ${ }^{1}$ Assistant Professor of Horticulture.

${ }^{2}$ Professor Emeritus and José Fernandez Chair of Crop Production.
'Texas Early Grano 502 PRR'. 'Temprana' is resistant to bolting and susceptible to pink root. 'Snow White' is an $F_{1}$ hybrid between inbreds selected from 'Cochise White' and 'White Sweet Spanish'. It was developed by the Utah Agricultural Experiment Station and jointly released with the U.S. Dept. of Agriculture in 1957. 'Snow White' produces large plants with semi-glossy foliage. It is a longproduces white globe-shaped bulbs of meday, 'White Sweet Spanish'-type onion that Farmington, N.M., in 2000. (severely infected roots). size to 1 ha. beyond the center of the bulb. to reveal the presence or absence of FBR. dium size that are firm, pungent, and store for long periods of time. 'White Sweet Spanish' was selected out of 'Utah Sweet Spanish', which originated from selections out of 'Spanish', which was introduced from Spain to the United States in 1916

The reciprocal crosses were made by intercrossing all parents in a common pollination cage, using honey bees as the pollen vector. Seeds from each parent were kept separate, and selections were made within each maternal line using phenotypic recurrent selection for pink root resistance, white bulb color, whole bulb firmness, and bulb shape in 1981. Selection was done at field maturity from spring seeding near Las Cruces, N.M. The selections were made from fields that contained high inoculum levels for Phoma terrestris (Hansen), causal organism of pink root, and Fusarium oxysporum f. sp. cepae [(H.N. Hans.) W.C. Snyder \& H.N. Hans], causal organism of Fusarium basal rot. Selec-

Table 1. Performance of 'NuMex Snowball' and other white onion cultivars tested as direct seeded and transplanted crops at Las Cruces, N.M., during the 1997, 1998, and 1999 growing seasons and at

\begin{tabular}{|c|c|c|c|c|c|c|c|}
\hline Cultivar & $\begin{array}{c}\text { Maturity } \\
(\mathrm{DAS})^{\mathrm{z}}\end{array}$ & $\begin{array}{l}\text { Pink } \\
\operatorname{root}^{y}\end{array}$ & $\begin{array}{c}\text { Marketable } \\
\text { yield } \\
(\%)^{\mathrm{x}}\end{array}$ & $\begin{array}{c}\text { Marketable } \\
\text { yield } \\
\left(\mathrm{t} \cdot \mathrm{ha}^{-1}\right)^{\mathrm{w}}\end{array}$ & $\begin{array}{c}\text { Avg } \\
\text { bulb wt } \\
(g)^{v}\end{array}$ & $\begin{array}{c}\text { Single } \\
\text { centers } \\
(\%)^{\mathrm{u}}\end{array}$ & $\begin{array}{c}\text { Fusarium } \\
\text { basal rot } \\
(\%)^{\mathrm{t}} \\
\end{array}$ \\
\hline \multicolumn{8}{|c|}{ 1997, Direct seeded } \\
\hline NuMex Snowball & 191 & --- & 87 & 90.9 & 301 & --- & --- \\
\hline NuMex Casper & 172 & --- & 94 & 76.9 & 259 & --- & --- \\
\hline Mean & 181 & --- & 91 & 83.9 & 280 & --- & --- \\
\hline $\mathrm{LSD}_{0.05}$ & $3^{* * *}$ & --- & $5^{*}$ & $9.2^{*}$ & $32^{*}$ & --- & --- \\
\hline \multicolumn{8}{|c|}{ 1998, Direct seeded } \\
\hline NuMex Snowball & 193 & 2.6 & 90 & 48.2 & 194 & --- & --- \\
\hline Aspen & 168 & 2.1 & 86 & 34.7 & 194 & --- & --- \\
\hline NuMex Casper & 165 & 1.9 & 89 & 46.3 & 192 & --- & --- \\
\hline Sierra Blanca & 166 & 3.1 & 90 & 44.7 & 237 & --- & --- \\
\hline Mean & 173 & 2.4 & 89 & 43.5 & 204 & --- & --- \\
\hline $\mathrm{LSD}_{0.05}$ & $3^{* * *}$ & $0.8^{*}$ & NS & NS & NS & --- & --- \\
\hline \multicolumn{8}{|c|}{ 1998-99, Transplanted } \\
\hline NuMex Snowball & 267 & 2.5 & 90 & 36.8 & 594 & 59.2 & 2.8 \\
\hline NuMex Casper & 253 & 1.6 & 91 & 59.1 & 472 & 41.7 & 17.9 \\
\hline Mean & 260 & 2.0 & 90 & 48.0 & 533 & 49.2 & 10.4 \\
\hline $\mathrm{LSD}_{0.05}$ & $6^{* * *}$ & NS & NS & $7.3^{* * *}$ & $73^{*}$ & NS & NS \\
\hline \multicolumn{8}{|c|}{ 1999, Direct seeded } \\
\hline NuMex Snowball & 196 & 4.1 & 82 & 55.0 & 394 & 60.6 & 9.0 \\
\hline Aspen & 179 & 4.3 & 88 & 40.5 & 269 & 45.2 & 17.7 \\
\hline Frosty & 198 & 5.0 & 83 & 32.7 & 258 & 74.8 & 13.3 \\
\hline La Nina & 179 & 4.3 & 91 & 53.1 & 245 & 73.6 & 4.8 \\
\hline NuMex Casper & 180 & 2.6 & 88 & 53.2 & 284 & 84.3 & 8.9 \\
\hline Sierra Blanca & 175 & 4.4 & 92 & 49.3 & 308 & 59.3 & 11.9 \\
\hline Mean & 184 & 4.1 & 87 & 47.3 & 293 & 66.3 & 10.9 \\
\hline $\operatorname{LSD}_{0.05}$ & $3^{* * *}$ & $1.1^{* *}$ & NS & $13.0^{*}$ & $51^{* * *}$ & $15.8^{* * *}$ & $7.5^{*}$ \\
\hline \multicolumn{8}{|c|}{ 2000, Direct seeded, Farmington } \\
\hline NuMex Snowball & --- & --- & 98 & 60.5 & 353 & --- & --- \\
\hline NuMex Casper & --- & --- & 93 & 42.2 & 223 & --- & --- \\
\hline Mean & --- & --- & 95 & 51.3 & 288 & --- & --- \\
\hline F ratio & --- & --- & NS & $29.0^{*}$ & $67.7^{* *}$ & --- & --- \\
\hline
\end{tabular}

${ }^{\mathrm{z}} \mathrm{A}$ plot was considered matured when at least $80 \%$ of the plant tops were down. Days after seeding.

yPink root rating. Root system of bulbs were rated based upon a rating scale of 1 (no infected roots) to 9

xPercentage of marketable yield was calculated by dividing marketable bulb weight by total bulb weight. ${ }^{\text {w}}$ Marketable yield $\left(\mathrm{t} \cdot \mathrm{ha}^{-1}\right.$ ) was calculated by weighing themarketable bulbs per plot and adjusting the plot

"Bulb weight was calculated by dividing the marketable bulbweight by the number of marketable bulbs. uThe percentage of bulbs with single centers (single growing point) was determined by cutting each bulbtransversely at the vertical center and measuring the number of growing points that extended $0.5 \mathrm{in}$.

'Percentage of bulbs with Fusarium basal plate rot (FBR). The basal plate of each bulb was transversely cut

ns, ${ }^{*}, *, * * *$ Nonsignificant or significant at $P=0.05,0.01$, or 0.001 , respectively. 
tions from each line were intercrossed and the resulting lines were kept separate. In 1981, 1983, and 1985, selections were made within each line and recombined after each selection. Selected bulbs from the third selection in 1985 were self-pollinated. Bulbs from the resulting $S_{1}$ progenies were selected (1987) within progeny families for relative bulb maturity. The latest maturing bulbs from 11 families were self-pollinated. Bulbs from the resulting progeny were selected for relative bulb maturity (1989) within progeny families. The latest maturing bulbs were recombined to form the next generation. Four cycles of phenotypic recurrent selection (1991, 1993, 1995, and 1997) were completed to improve the population for bulb color, quality, pink root resistance, maturity uniformity, bulb uniformity, bulb shape, firmness, and percentage of single centers.

Selection for pink root resistance was accomplished by planting selections in fields that were severely infested with $P$. terrestris. At bulb maturity, bulbs were rated for the incidence of pink roots. Only bulbs that possessed a healthy root system with minimal symptoms of pink root were selected. Bulbs were selected for uniform round globe shape. Selection for bulb scale color was based on the color of the dry outer bulb scales. Selection for bulb shape and color was subjective, based on visual observation. Selection for bulb firmness was based on a subjective evaluation of the amount of bulb scale resistance when bulbs were squeezed by hand. Selection for bulb maturity was to select bulbs that matured the last week of July. Selection for a single grow- ing point per bulb was accomplished by transversely cutting selected bulbs at the vertical center of each bulb. Bulbs with a single growing point or multiple growing points within 1.3 $\mathrm{cm}$ from the center of the bulb were selected and advanced to the next cycle by planting the bottom half of the bulb.

\section{Description and performance}

'NuMex Snowball' is an intermediate-day, round onion that matures from 25 July to 5 Aug. when spring-seeded in Las Cruces, N.M. The suggested planting dates at Las Cruces are 15 Jan. to 1 Mar. 'NuMex Snowball' has excellent yield and firmness, a moderate percentage of single-centered bulbs, and large, white, round bulbs. 'NuMex Snowball' matures at a time when few other white cultivars mature.

Replicated field trials were conducted in 1997, 1998, and 1999 comparing 'NuMex Snowball' to 'Aspen', 'Frosty', 'La Nina', 'NuMex Casper', and 'Sierra Blanca' (Table 1 ). These cultivars are commonly grown commercially in New Mexico as spring-seeded, white onions. 'NuMex Snowball' matured 2 weeks later than the other cultivars (Table 1). The pink root resistance of 'NuMex Snowball' was comparable to other cultivars except 'NuMex Casper', which possessed greater pink root resistance (Table 1). The percentage of marketable bulbs of 'NuMex Snowball' was comparable to other cultivars (Table 1). Under high-density plantings in 1998, 'NuMex Snowball' produced a comparable bulb yield and size as other cultivars (Table 1). Larger spac- ings between plants as in 1997 and 1999 produced 'NuMex Snowball' bulbs greater in size than any of the other cultivars (Table 1). 'NuMex Snowball' produced a comparable yield from direct seeding as 'La Nina', 'NuMex Casper', and 'Sierra Blanca' and a greater yield than 'Aspen' and 'Frosty' (Table 1). 'NuMex Snowball' yields from transplants were lower than from direct seeding because of a higher percentage of bolting and uprooting associated with transplant production. 'NuMex Casper' had a higher yield as a transplant than 'NuMex Snowball'. 'NuMex Snowball' produced a comparable percentage of bulbs with single centers with all cultivars except 'NuMex Casper' (Table 1). The incidence of Fusarium basal rot was similar among all cultivars except ‘Aspen' (Table 1).

\section{Availability}

Currently, 'NuMex Snowball' is being produced, marketed, and sold exclusively by Lockhart Seed Co., Stockton, Calif. Plant Variety Protection certificate number 200000351 has been issued.

\section{Literature Cited}

Corgan, J.N. 1984. 'NuMex BR 1' onion. HortScience 19:593

Enzie, J.V. and J.N. Corgan. 1979. Temprana. An early maturing white grano onion. N.M. State Univ. Coop. Ext. Serv. Circ. 488.

Garcia, F. and A.B. Fite. 1931. Early grano onion culture. N.M. Agr. Expt. Sta. Bul. 193.

Hawthorn, L.R. 1944. Texas grano onion. Texas Agr. Expt. Sta. Prog. Rpt. 899. 